\title{
ODBUDOWA GMACHU DOŚWIADCZALNEGO SZKOŁY GŁÓWNEJ HANDLOWEJ W WARSZAWIE PO II WOJNIE ŚWIATOWEJ
}

W związku z wpisaniem w 2008 r. kampusu Szkoły Głównej Handlowej do rejestru zabytków wzrosło zainteresowanie przeszłością zabytkowego zespołu uczelnianych budynków i jego otoczeniem. Badania, które do tej pory skupiały się głównie na historii uczelni ${ }^{1}$, zostały rozszerzone na historię jej budynków. W wyniku czteroletnich badań, prowadzonych w ramach grantu Narodowego Programu Humanistyki pod kierunkiem naukowym prof. Janusza Kalińskiego, powstało m.in. wirtualne muzeum SGH oraz pierwsza praca w całości poświęcona historii kampusu, w której w zarysie przedstawiono losy zabytkowych budynków na szerokim tle rozwoju całego Mokotowa, ze szczególnym uwzględnieniem dziejów Pól Mokotowskich².

Celem artykułu jest przedstawienie procesu odbudowy po II wojnie światowej najstarszego budynku kampusu SGH - pawilonu doświadczalnego, obecnie nazywanego Budynkiem A. W wyniku działań wojennych był on najbardziej zniszczonym obiektem na terenie kampusu; na początku listopada 1944 r., już po zakończeniu powstania warszawskiego został podpalony przez wojska niemieckie. Podstawę źródłową tekstu stanowią materiały archiwalne, zebrane w czasie kwerendy w Archiwum m.st. Warszawy oraz Archiwum Szkoły Głównej Handlowej. Na potrzeby badań nad tym zagadnieniem szczególnie cenne okazały sie dokumenty Biura Odbudowy Stolicy, dostarczające wielu faktów nieznanych wcześniej w literaturze naukowej.

1 Szkoła Główna Handlowa w latach 1939-1945, red. J. Nowicki, „Monografie i Opracowania” nr 187, Wydawnictwa Uczelniane SGPiS, Warszawa 1986; Historia Szkoły Głównej Handlowej w Warszawie, 1906-2006, red. W. Morawski, Oficyna Wydawnicza SGH, Warszawa 2006; Wyższa Szkoła Handlowa, Szkoła Główna Handlowa, Miejska Szkoła Handlowa 1906-1945, „Monografie i Opracowania” nr 134, Wydawnictwa Uczelniane SGPiS, Warszawa 1984; I. Kostrowicka, Szkoła Główna Planowania i Statystyki w Warszawie, w: Nauka i szkolnictwo wyższe w Warszawie, PWN, Warszawa 1987, s. 416-431; J. Macieja, S. Wrzosek, Szkoła Główna Planowania i Statystyki w Warszawie, w: Dzieje Mokotowa, PWN, Warszawa 1972, s. 421-433; Działalność dydaktyczna Wyższej Szkoły Handlowej - Szkoły Głównej Handlowej w latach 1915-1939, „Monografie i Opracowania” nr 388, Oficyna Wydawnicza SGH, Warszawa 1994.

2 Historia zabytkowego kampusu Szkoły Głównej Handlowej w Warszawie, red. W. Morawski, Oficyna Wydawnicza SGH, Warszawa 2015. 
W mniejszym zakresie wykorzystano literaturę wspomnieniową oraz prasę z drugiej połowy lat $40 . \mathrm{XX}$ w.

\section{Pawilon doświadczalny do 1944 r.}

Początki Szkoły Głównej Handlowej sięgają 1906r., kiedy powstały Prywatne Kursy Handlowe Męskie Augusta Zielińskiego, których pierwsza siedziba mieściła się w wynajętym lokalu przy ul. Smolnej. W 1909 r. przemianowano nazwę szkoły na Wyższe Kursy Handlowe im. A. Zielińskiego. W czasie I wojny światowej okupujący Warszawę Niemcy nadali uczelni rangę „Handelshochschule” pod warunkiem zachowania jej apolityczności. Z tego okresu wywodzi się nazwa Wyższa Szkoła Handlowa ${ }^{3}$. Po odzyskaniu przez Polskę niepodległości duże zapotrzebowanie na wysoko wykwalifikowane kadry dla administracji państwowej spowodowało, że studia ekonomiczne cieszyły się bardzo dużym zainteresowaniem. Wkrótce okazało się, że siedziba Szkoły, znajdująca się od 1911 r. przy ul. Koszykowej, nie jest w stanie pomieścić wszystkich studentów. W związku z problemami lokalowymi Wyższej Szkoły Handlowej władze uczelni rozpoczęły zabiegi o nową lokalizację. W 1923 r. starania dyrekcji WSH zakończyły się sukcesem. Szkole przydzielono teren na Mokotowie, przy ul. Rakowieckiej 6. Plac, który znajdował się w bezpośrednim sąsiedztwie do planowanej trasy N-S i al. Niepodległości, został przekazany WSH w dzierżawę na okres 99 lat ${ }^{4}$.

Gdy WSH uzyskała prawo do dzierżawy terenu przy ul. Rakowieckiej, powołano Komitet Budowlany pod przewodnictwem wiceministra skarbu - Bolesława Markowskiego. W lutym 1924 r. zapadła decyzja o realizacji projektu J. Koszczyc-Witkiewicza $^{5}$. Już w czerwcu 1924 r. po naniesieniu poprawek projekt złożono w Ministerstwie

\footnotetext{
3 J. Kaliński, Szkoła Główna Handlowa 1906-1996 (Wykład wygłoszony 17 kwietnia 1996r.), w: Z obchodów 90-lecia Szkoły Głównej Handlowej, Oficyna Wydawnicza SGH, Warszawa 1996, s. 8.

4 A. Jarosz-Nojszewska, Wyższa Szkoła Handlowa 1915-1933, w: Historia Szkoły Głównej Handlowej $w$ Warszawie..., op.cit., s. 43-64.

5 Jan Witkiewicz-Koszczyc (1881-1958), architekt i konserwator zabytków, w swojej twórczości łączył nowoczesne koncepcje architektoniczne $\mathrm{z}$ tradycyjnymi elementami architektury polskiej. Był bratankiem Stanisława Witkiewicza i stryjecznym bratem Witkacego. W czasie studiów architektonicznych w Monachium zaczął używać przydomku Koszczyc, pochodzącego od panieńskiego nazwiska prababki, Anieli z Koszczyców Szemiothowej. Początkowo był to tylko pseudonim w jego politycznej, konspiracyjnej działalności w środowisku polskich studentów, później jednak stał się integralną częścią nazwiska. Koszczyc zaprojektował i wybudował wiele obiektów w Kazimierzu Dolnym (m.in. Szkołę Rzemiosł Budowlanych, Dom Kifnerów, Dom Potworowskich, Łaźnie Miejskie, odbudował i konserwował Kamienicę Celejowską i Kamienicę Przybyłów) i Nałęczowie (m.in. willa Brzozy, Apteka), od 1925 r. zamieszkał w Warszawie, gdzie rozpoczął budowę kampusu WSH. M. Leśniakowska, Architekt Jan Koszczyc Witkiewicz (1881-1958)
} 
Wyznań Religijnych i Oświecenia Publicznego ${ }^{6}$.Zakładał on budowę głównego pawilonu od strony projektowanej trasy $\mathrm{N}-\mathrm{S}$ oraz pawilonu doświadczalnego od strony ul. Rakowieckiej i pawilonu bibliotecznego od projektowanej ul. Batorego. Rozwiązanie takie przyjęto ze względu na niedostatek środków finansowych i możliwość etapowego realizowania budowy całego kampusu? .

Prace budowlane rozpoczęto w listopadzie 1924 r., w październiku $1925 \mathrm{r}$. budynek był już wzniesiony w stanie surowym, a 24 listopada 1926r. został oddany do użytku. Zajęcia w nowym budynku rozpoczęly się 10 września 1926 r. Koszty budowy wynoszące 2,4 mln zł zostały pokryte z dotacji Ministerstwa Wyznań Religijnych i Oświecenia Publicznego ${ }^{8}$. Dnia 6 listopada 1927 r. odbyła się uroczystość poświęcenia nowego gmachu' ${ }^{9}$ Przed wojną na terenie należącym do SGH wybudowano jeszcze dwa budynki - bibliotekę oraz dom mieszkalny dla pracowników szkoły.

W listopadzie 1939 r. pawilon doświadczalny zajęło wojsko niemieckie, po którego ustąpieniu miał się tam mieścić szpital dla zakaźnie chorych. Jednak w styczniu 1940 r. budynek przeznaczono na składnicę akt Archiwum Akt Nowych (AAN). Stopniowo przewieziono tam znaczną część akt polskich urzędów, które zajęły około 34800 m bieżących. Ich waga wynosiła 1200-1400 t, czyli blisko 100 wagonów. Na Rakowiecką zwieziono nie tylko akta różnych instytucji, lecz także księgozbiory niektórych ministerstw, instytucji i osób prywatnych. Po upadku powstania warszawskiego, zgodnie z podpisaną w Ożarowie umową kapitulacyjną pomiędzy przedstawicielami polskich władz powstańczych a Niemcami, Niemcy upoważnili stronę polską do ewakuacji mienia ocalonego w czasie działań wojennych. Mimo tych ustaleń po upadku powstania wojska niemieckie rozpoczęły systematyczne podpalanie miasta. W tym okresie spalono Archiwum Miejskie, Bibliotekę Krasińskich, Archiwum Główne Akt Dawnych, Archiwum Skarbowe. Ten sam los spotkał Budynek A należący do SGH, ponieważ znajdowały się w nim wówczas zwiezione w czasie okupacji dokumenty Archiwum Akt Nowych ${ }^{10}$.

\footnotetext{
i budowanie w jego czasach, Instytut Sztuki PAN, Warszawa 1998, s. 9; M. Paprotny, Jan Koszczyc-Witkiewicz - twórca gmachów SGH, „Mówią wieki” 2006, nr 4, s. 29-31.

6 Projekt został zatwierdzony przez Wydział Budowlany Ministerstwa Wyznań Religijnych i Oświecenia Publicznego dnia 16 września 1924 r., a następnie przez Departament Budowlany Ministerstwa Robót Publicznych dnia 8 października 1924 r. J. Witkiewicz-Koszczyc, Sprawozdanie z budowy gmachu doświadczalnego Wyższej Szkoły Handlowej w Warszawie, Wyższa Szkoła Handlowa w Warszawie, Warszawa 1927, s. 12; M. Leśniakowska, op.cit., s. 226.

7 W. Mróz, Działalność dydaktyczna Wyższej Szkoły Handlowej - Szkoły Głównej Handlowej w latach 1915-1939, Oficyna Wydawnicza SGH, Warszawa 1994, s. 79.

8 J. Witkiewicz-Koszczyc, op.cit., passim; W. Mróz, op.cit., s. 67; A. Jarosz-Nojszewska, Powstanie Szkoły Głównej Handlowej w Warszawie i jej kampusu, w: Historia zabytkowego..., op.cit., s. 49-60.

$9 \quad$ M. Leśniakowska, op.cit., s. 227.

10 A. Podolska-Meducka, Wojenne losy Kampusu, w: Historia zabytkowego..., op.cit., s. 69-93.
} 


\section{Powojenna odbudowa Mokotowa}

W styczniu 1945 r., gdy pierwsi pracownicy SGH przybyli na teren kampusu, pawilon A był bardzo zniszczony. Nie uległ natomiast zniszczeniu budynek Biblioteki SGH. W związku w tym właśnie w budynku Biblioteki SGH zamieszkali pracownicy Szkoły, którzy starali się nie dopuścić do rozkradania ocalałego majątku uczelni. Leon Koźmiński tak wspominał pierwsze powojenne tygodnie: „Mieszkaliśmy z A. Grodkiem w gmachu biblioteki, śpiąc na porzuconych przez uciekające wojska materacach i starając się nie dopuścić do «rozszabrowania» wszystkiego co pozostało. Załoga chroniąca majątek Uczelni korzystała z miesięcznej zapomogi wynoszącej wówczas $1500 \mathrm{zł}$ dla docenta, a 2000 dla profesora, z zupy wydawanej z kuchni przy ul. Puławskiej, miesięcznego przydziału słoniny i ochrony posterunku wojskowego. Wodę otrzymywano topiąc śnieg, a po pewnym czasie gdy zabrakło śniegu, przynosząc ze studni przy jednym z domów przy al. Niepodległości. Ogrzewanie odbywało sie przez palenie ogrodzenia cmentarza żołnierzy niemieckich poległych w czasie powstania w «kozach» zainstalowanych w niektórych pomieszczeniach. Dużym kłopotem była walka $\mathrm{z}$ «szabrem»"11.

Pawilon doświadczalny był jednym z najbardziej zniszczonych budynków w najbliższej okolicy. Warto bowiem zaznaczyć, że na ul. Rakowieckiej zniszczenia wojenne nie były duże, ponieważ do ostatnich chwil przed wkroczeniem Armii Czerwonej do lewobrzeżnej Warszawy stacjonowały tu wojska niemieckie. W stanie niemal nienaruszonym przetrwał wojnę, sąsiadujący z SGH, kompleks budynków wzniesionych dla Głównej Biblioteki Wojskowej. Po wojnie ulokowały się tam biura Ministerstwa Administracji Publicznej oraz Ministerstwa Kultury i Sztuki ${ }^{12}$. W miarę dobrej kondycji był też kompleks gmachów SGGW, zlokalizowany na działce przy ul. Rakowieckiej $8^{13}$. Zniszczone były budynki Instytutu Geologicznego, znajdującego się

\footnotetext{
11 L. Koźmiński, Sytuacja po zakończeniu wojny, w: Szkoła Główna Handlowa..., op.cit., s. 134.

12 Ulica Rakowiecka kończy swoją odbudowe, „Stolica” 1947, nr 21, s. 2; Kto odbudowuje Warszawę, „Stolica" 1947, nr 34, s. 6-7.

13 Spośród budynków SGGW przy ul. Rakowieckiej 8 zniszczeniu i spaleniu uległ pawilon Botaniki Ogólnej i pawilon Zakładu Architektury Krajobrazu. Ocalały, były jednak obrabowane z wyposażenia wewnętrznego oba główne gmachy uczelni wraz ze zbiorami znajdującej się w nich Biblioteki Głównej. Budynki przy ul. Rakowieckiej 8 ocalały, ponieważ podczas powstania warszawskiego i później były, podobnie jak budynki SGH, obsadzone przez oddziały Luftwaffe. Dużych strat nie poniosła też biblioteka SGGW, która straciła około 8\% swoich przedwojennych zbiorów. Dzięki temu SGGW szybko uruchomiła zajęcia dla studentów. Andrzej Zalewski, który był wówczas studentem SGGW, tak wspominał atmosferę związaną z uruchomieniem uczelni: „Początkowo wydawało się, że rząd Polski Ludowej, który z Lublina przeniósł się na Pragę, nie pozwoli na uruchomienie uczelni, uważanej przez komunistów za elitarną szkołę ziemiańskiej młodzieży. Jednak obok, też na Rakowieckiej, ruszyła Szkoła Główna Handlowa, która podobnie miała opinię szkoły dla bogatych, młodych ludzi z poprzedniej epoki. [...] SGGW, obok SGH, była pierwszą uczelnią uruchomioną
} 
u zbiegu ulic Rakowieckiej i Wiśniowej. Jednak gmach główny Instytutu odbudowano już w 1946 r., a w odnowionym hallu głównym tego budynku umieszczono wystawę Przemysłu Ziem Odzyskanych. Pozostałe trzy pawilony należące do Instytutu, zlokalizowane głębiej w ogrodzie, które były spalone w czasie wojny, odbudowywano w latach 1946-1947'14. W dobrym stanie był znajdujący się też przy ul. Rakowieckiej budynek Gimnazjum im. Rejtana. Po wojnie był wykorzystywany na potrzeby kilku szkół (lekcje odbywały się na trzy zmiany). Prowadzono w nim też wykłady dla studentów Politechniki Warszawskiej ${ }^{15}$.

Szybko wyremontowano również budynki mieszkalne w najbliższej okolicy. Najcenniejsze ocalałe w tym rejonie kamienice i wille zostały szybko zawłaszczone przez komunistyczne władze ${ }^{16}$. Nie pozwolono powrócić do nich przedwojennym lokatorom. Ich mieszkania zajęły osoby związane z nowym reżymem. Wielkie zniszczenia w innych dzielnicach powodowały też, że część domów mieszkalnych władze przejmowały na potrzeby nieposiadających swoich budynków biur i instytucji rządowych ${ }^{17}$. Odremontowane budynki w tej okolicy zajmowali głównie pracownicy instytucji państwowych. W domach przy ul. Rakowieckiej, pomiędzy poprzecznymi ulicami - Akacjową i Fałata - zamieszkali pracownicy Ministerstwa Administracji Publicznej; w sąsiednich budynkach - urzędnicy Ministerstwa Leśnictwa, Ministerstwa Odbudowy i Biura Kontroli. Budynek znajdujący się na rogu ul. Rakowieckiej i al. Niepodległości był siedzibą biur Centralnego Zarządu Przemysłu Paliw Płynnych ${ }^{18}$. Domy przy ul. Kazimierzowskiej 79 i ul. Rakowieckiej 33 wyremontowano dla pracowników więzienia przy Rakowieckiej i Ministerstwa Bezpieczeństwa Publicznego ${ }^{19}$. Z kolei przy al. Niepodległości, w budynku Centralnego Urzędu Patentowego, którego budowy przed wojną nie ukończono, a który do stanu używalności doprowadzono na zlecenie Ministerstwa Przemysłu, ulokowano Centralny Zarząd Energetyki

po wojnie w Warszawie, stąd pierwsze gazety stale opisywały nasze życie”. [Pierwsi powojenni. Wspomnienia pierwszych powojennych studentów Wydziału Rolniczego SGGW, Fundacja Rozwój SGGW, Warszawa 2002, s. 164-165]. SGGW rozpoczęła rok akademicki 1944/45 w dniu 15 maja i trwał on bez zmniejszania pensum i bez zmiany planów nauczania do 17 listopada. Stary gmach SGGW przeznaczono na zakłady naukowe, a nowy, wybudowany w 1939 r., na bursę. Szkoła Główna Gospodarstwa Wiejskiego w Polsce Ludowej 1945-1956, red. W. Herman, w: Księga pamiątkowa Szkoły Głównej Gospodarstwa Wiejskiego w Warszawie 1906-1956, t. 1, PWRiL, Warszawa 1958, s. 106-107; J. Górski, Warszawa w latach 1944-1949. Odbudowa, PWN, Warszawa 1988, s. 450; A. Mężyński, Biblioteki Warszawy w latach 1939-1945, Ministerstwo Kultury i Dziedzictwa Narodowego, Warszawa 2010, s. 294.

14 Ulica Rakowiecka..., op.cit.; Kto odbudowuje Warszawę, op.cit.

15 Ibidem.

16 Szerzej na ten temat patrz: P. Tanewski, Wokół SGH: domy, ludzie, zdarzenia, Oficyna Wydawnicza SGH, Warszawa 2012; P. Tanewski, Wokół SGH: domy, ludzie, zdarzenia, t. 2, Oficyna Wydawnicza SGH, Warszawa 2014.

17 Warszawa wielkomiejska. Plac Unii i okolice, EKBIN Studio PR Ewa Kielak, Warszawa 2013, s. 93.

18 Ulica Rakowiecka..., op.cit.

19 Warszawa wielkomiejska..., op.cit. 
i Urząd Patentowy ${ }^{20}$. Przy al. Niepodległości znajdowały się także budynki przeznaczone dla pracowników Centralnego Zarządu Przemysłu Cukrowniczego (nr 159), Polskiego Banku Narodowego (nr 138), Ministerstwa Skarbu, zaś u zbiegu al. Niepodległości i ul. Madalińskiego budowano duże osiedle mieszkaniowe dla pracowników Ministerstwa Bezpieczeństwa Publicznego ${ }^{21}$. Niedaleko, przy ul. Chocimskiej, swoją siedzibę miało też Biuro Odbudowy Stolicy.

\section{Biuro Odbudowy Stolicy a odbudowa gmachu A}

Plany powojennej odbudowy Warszawy w latach 1945-1949 były opracowywane przez Zespół Wydziału Urbanistyki Biura Odbudowy Stolicy. Pierwsza wersja planu została przedstawiona członkom rządu do akceptacji 5 marca 1945 r. Plan ten nawiązywał do przedwojennych projektów Warszawskiego Zespołu Miejskiego. Poszczególne jego wersje służyły wówczas do podejmowania najpilniejszych decyzji związanych m.in. z rozbiórką obiektów, które ze względu na stan zachowania, a często ze względów ideologicznych nie powinny zostać odbudowane ${ }^{22}$. Szczegółowy plan zabudowy Mokotowa został opracowany jako jeden z pierwszych. Początkowo objęto nim kwadrat pomiędzy ulicami Rakowiecką, Odyńca, Puławską i św. Andrzeja Boboli. Był to obszar, który stanowił jeden z najmniej zniszczonych przez działania wojenne fragmentów Warszawy ${ }^{23}$.

Z uwagi na stopień zniszczenia budynku SGH znajdującego się od strony ul. Rakowieckiej oraz jego lokalizację Biuro Odbudowy Stolicy podjęło decyzję o szybkiej odbudowie gmachu A na potrzeby Politechniki Warszawskiej, która była, obok Uniwersytetu Warszawskiego, najbardziej zniszczoną uczelnią Warszawy ${ }^{24}$. Dnia

\footnotetext{
20 Ministerstwo Przemysłu i Handlu w al. Niepodległości, „Stolica” 1947, nr 22, s. 2.

21 Pot., Reporterska włóczęga. Aleja Niepodległości, „Stolica” 1947, nr 35, s. 4.

22 L. Królikowski, M. Ostrowski, Rozwój przestrzenny Warszawy, Mazowieckie Centrum Kultury i Sztuki Agencja Wydawnicza Egros, Warszawa 2009, s. 142.

23 J. Hryniewiecki, Szczegółowy plan zabudowy Mokotowa, „Stolica” 1947, nr 9, s. 4.

24 W czasie powstania i podczas planowych wyburzeń przeprowadzonych przez Niemców po powstaniu budynki Politechniki uległy prawie całkowitemu zniszczeniu. Całkowicie spalona była Biblioteka Główna Politechniki. Ocalał jedynie mały budynek przy ul. Nowowiejskiej, który został tymczasową siedzibą władz uczelni, oraz kreślarnia. W tej sytuacji od 1945 r. Politechnikę trzeba było budować praktycznie od nowa. [Politechnika Warszawska 1915-1965, PWN, Warszawa 1965, s. 322; A. Mężyński, op.cit., s. 294; S. Buczek, Politechnika, „Stolica” 1947, nr 10, s. 5]. Szczegółowy opis stanu poszczególnych budynków PW w $1945 \mathrm{r}$. znajduje się w pracy: Dziesięć lat Politechniki Warszawskiej w Polsce Ludowej, red. H. Śmigielski, PWN, Warszawa 1955, s. 85-88. W kwietniu 1945 r. profesorowie Politechniki zdecydowali, że zostaną opracowane i uzgodnione z BOS projekty uruchomienia na jesieni w Warszawie wydziałów: Architektury, Inżynierii i Geodezji. W maju, podczas zebrania, w którym wzięli udział także przedstawiciele nowych władz,
} 
14 czerwca 1945 r. inż. Bohdan Lachert powiadomił architekta Jana Koszczyc-Witkiewicza, że Biuro Odbudowy Stolicy podjęło decyzję o powierzeniu mu kierowania odbudową gmachu ${ }^{25}$. Tego samego dnia Jan Koszczyc-Witkiewicz w towarzystwie przedstawiciela BOS dokonał oględzin spalonego gmachu, a trzy dni późnej sporządził i złożył sprawozdanie o stanie budynku dla Biura Odbudowy Stolicy. Przeprowadził wówczas oględziny murów zewnętrznych, żelbetonowej konstrukcji szkieletowej budynku, łuku żelbetowego nad audytorium, stropów, dachów oraz tarasów. Stwierdził, że na skutek pożaru została przepalona i złuszczona powłoka betonowa słupów żelbetowych okrągłych znajdujących się w korytarzu wejściowym, w czego efekcie zostały obnażone uzwojenia, a miejscami także pręty pionowe słupów. Belki stropowe były popękane, miejscami nawet się uginały, zaś stropy miały rysy w żebrach i spoinach między pustakami. W łuku żelbetowym nad aulą i w słupach podpierających ten łuk zostały obnażone pręty zbrojeń wskutek przepalenia otulającej je warstwy betonu. Dach i tarasy znajdujące się nad budynkiem poza drobnymi rysami nie wykazywały większych uszkodzeń. W narożniku budynku znajdującym się od strony ogrodu było pęknięcie, ciągnące się od okien parteru aż do fundamentów. W tej sytuacji wskazane było założenie na pęknięciu pasków obserwacyjnych w celu ustalenia, czy zachodzą dalsze odkształcenia. W najgorszym stanie był narożnik od ul. Rakowieckiej po stronie zachodniej, gdzie ceglane obłożenie konstrukcji żelbetonowej na całej wysokości, tj. około $15 \mathrm{~m}$, oddzieliło się od słupa i istniało ryzyko, że przy wstrząsach wywołanych ruchem ulicznym może runąć. Oznaczało to konieczność jak najszybszego rozebrania oddzielonej części murów ${ }^{26}$. Na potrzebę szybkiej interwencji w tej sprawie wskazywała także inspekcja BOS z sierpnia $1945 \mathrm{r}^{27}$

potwierdzono koncepcję uruchomienia tych trzech wydziałów o łącznej liczbie studentów około 1200. Warto jednak zaznaczyć, że władze PW protestowały przeciwko planom BOS przeniesienia uczelni na inny teren w Warszawie, uznając te plany „za nieżyciowe i z punktu widzenia państwowego za szkodliwe”. Politechnika Warszawska w ćwierćwieczu Polski Ludowej, Wydawnictwa Politechniki Warszawskiej, Warszawa 1970, s. 16; Dziesięciolecie Politechniki Warszawskiej w Polsce Ludowej 1945-1955, Wydawnictwa Politechniki Warszawskiej, Warszawa 1956, s. 85-90; Politechnika Warszawska 1915-1965, op.cit., s. 321-323.

25 Archiwum m.st. Warszawy, BOS, syg. 5852; Bohdan Lachert (1900-1987), architekt, absolwent Politechniki Warszawskiej. W okresie międzywojennym należał do grupy Praesens. Otrzymał nagrodę Grand Prix za Pawilon Polski na Wystawie Sztuki w Paryżu w 1937 r. W czasie wojny był zaangażowany w tajne nauczanie. Od 1944 r. profesor Politechniki Warszawskiej. W latach 1944-1945 dyrektor Departamentu Projektowania PKWN. Według jego projektów wybudowano osiedle mieszkaniowe na Muranowie i cmentarz Mauzoleum Żołnierzy Radzieckich w Warszawie. W BOS kierował Wydziałem Architektury i Inżynierii. Encyklopedia Warszawy, Wydawnictwo Naukowe PWN, Warszawa 1994, s. 407; Kto jest kim w Polsce 1984. Informator biograficzny, Wydawnictwo Interpress, Warszawa 1984, s. 510-511; Warszawska Szkoła Architektury. 50-lecie Wydziału Architektury Politechniki Warszawskiej, PWN, Warszawa 1967, s. 244; M. Sikorska, Biuro Odbudowy Stolicy - organizacja, zadania, pracownicy, w: Archiwum Biura Odbudowy, Stowarzyszenie Przyjaciół Archiwum Państwowego m.st. Warszawy, Warszawa 2012, s. 9-14.

26 Archiwum m.st. Warszawy, BOS, syg. 5852.

27 Archiwum m.st. Warszawy, BOS, syg. 6585. 
Dnia 7 lipca był gotowy, opracowany przez Witkiewicza, wstępny kosztorys prac. Jednak BOS z uwagi na krótki czas, jaki pozostał do rozpoczęcia roku akademickiego, zadecydowało o przeprowadzeniu robót remontowych w minimalnym zakresie. Prowizoryczne przygotowanie gmachu dla Wydziału Architektury miało objąć: oczyszczenie gmachu, reperację płyty żelbetowej dachowej i pokrycia dachowego, wykonanie i oszklenie okien, wykonanie ścianek rozdzielających audytoria oraz drzwi, pobielenie ścian i sufitów oraz przeprowadzenie robót niezbędnych do zapewnienia podstawowej wygody użytkowania budynku, jak np. remonty centralnego ogrzewania i toalet. Ułożenie posadzek oraz dalsze prace remontowe mające na celu doprowadzenie budynku do stanu pierwotnego miały zostać przeprowadzone w okresie późniejszym, już po rozpoczęciu roku akademickiego. Dnia 25 czerwca 1945 r. Wydział Architektury BOS skierował na okres tygodnia do prac przy spalonym Budynku A dwóch murarzy i dwudziestu niewykwalifikowanych robotników, którzy mieli za zadanie oczyścić wnętrze gmachu, zebrać pozostałe, przydatne do dalszego użytku okucia i urządzenia oraz wykonać podstawowe roboty porządkowe. Jednak prace nie zaczęły się tak szybko jak planowano. W dniu 10 lipca BOS był zmuszony wystosować ponaglenie, ponieważ nie rozpoczęto wstępnych prac porządkowych ${ }^{28}$.

Dnia 14 lipca przystąpiono do oczyszczania gmachu z zalegającego w nim popiołu. Z uwagi na fakt, że spalonych dokumentów było bardzo dużo, prace znacznie przeciągnęły się w czasie. Według obliczeń Jana Koszczyc-Witkiewicza jeden robotnik nie był w stanie wynieść więcej niż $1 \mathrm{~m}^{3}$ popiołu dziennie. Tymczasem pierwszego dnia liczba robotników (do prac porządkowych przysłano brygadę pracy złożoną z żołnierzy) wyniosła 20, w kolejnych 60, aby 22 lipca spaść do 37 osób. W tej sytuacji 23 lipca Jan Koszczyc-Witkiewicz alarmował BOS, że przy takim tempie pracy oczyszczanie budynku z popiołu potrwa jeszcze $40 \mathrm{dni}$, albowiem pozostało do wyniesienia około $2110 \mathrm{~m}^{3}$ popiołu ${ }^{29}$. Architekt zwracał uwagę, że pod popiołem, pod dawną podłogą, we wszystkich salach znajduje się instalacja wodna, kanalizacyjna i gazowa, którą należy zbadać i wycenić jej naprawę lub usunięcie. Później należy oskrobać ściany, sufity i konstrukcje żelbetonowe, a następnie wyrzucić gruz. Dopiero potem mogą rozpocząć się istotne prace remontowe. W tej sytuacji nie jest możliwe wykończenie gmachu na potrzeby Politechniki Warszawskiej do jesieni. Witkiewicz prosił

28 Archiwum m.st. Warszawy, BOS, syg. 5852.

29 Ibidem. Tak duże ilości popiołu znajdowały się w gmachu A w wyniku spalenia w nim dużej ilości akt, należących do Archiwum Akt Nowych. AAN zostało powołane do życia 1 sierpnia 1930 r. Początkowo jego siedzibą był budynek przy ul. Długiej 13. Później przenosiło się kolejno na ul. Szpitalną i W. Górskiego. Na początku października 1939 r. Niemcy przeprowadzili Archiwum do budynku przy ul. Rakowieckiej 6, równocześnie wyrzucając z niego część zbiorów Biblioteki SGH. Po upadku powstania, 3 października 1944 r. oddziały niemieckie podpaliły budynek przy ul. Rakowieckiej 6 i zbiory spłonęły całkowicie. W. Wysocki, Archiwum Akt Nowych w Warszawie 1930-1946. Dzieje i działalność, „Teki Archiwalne” 2004, t. 8, s. 19-28. 
o zwiększenie liczby robotników do 80 oraz dowożenie im na Rakowiecką obiadów w celu skrócenia do minimum przerwy obiadowej.

Początkowo gruz i popiół usuwano z wnętrza gmachu na teren ulicy, co skutecznie uniemożliwiało dalsze prace remontowe. $W$ drugiej połowie lipca popiół usuwany z gmachu A zasypywał całą ulicę Rakowiecką. Początkowo popiół usuwano $\mathrm{z}$ budynku, wywożąc go na taczkach, jednak na początku sierpnia zaczęto wyrzucać go za pomocą długich drewnianych rynien, co pozwoliło zmniejszyć liczbę osób zatrudnionych przy robotach porządkowych do 12. Jeszcze w połowie sierpnia popiół zalegał na ulicy Rakowieckiej, albowiem firma, która wygrała przetarg na jego wywiezienie, nie przystąpiła do pracy.

Dopiero 28 lipca 1945 r. Roman Piotrowski oficjalnie zlecił J. Koszczyc-Witkiewiczowi wykonanie prac przygotowawczych i sprawowanie kierownictwa robót przy remoncie budynku SGH na pomieszczenie tymczasowe dla Wydziału Architektury Politechniki Warszawskiej. Prace przy porządkowaniu budynku były w tym momencie już dość zaawansowane, a 24 lipca podjęto decyzję o ogłoszeniu przetargu na odbudowę gmachu SGH ${ }^{30}$. W czasie drugiej lustracji BOS, przeprowadzonej 12 sierpnia 1945 r., Budynek A był już w trakcie remontu, w dalszym ciągu jednak natychmiastowej interwencji wymagał stan jednego z narożnych filarów budynku ${ }^{31}$.

\section{Profesor Stanisław Skrzywan i odbudowa gmachu A}

Senat SGH bardzo późno został poinformowany o planach BOS przekazania budynku Politechnice. Dopiero w lipcu 1945 r., kiedy zaczęto przygotowywać budynek do potrzeb Politechniki, prof. Leon Koźmiński przedstawił na posiedzeniu Senatu SGH sprawę odbudowy gmachu A oraz przekazania jego części na trzy lata Wydziałowi Architektury Politechniki Warszawskiej. Członkowie Senatu zgodzili się w zasadzie na odstąpienie połowy gmachu, byli jednak zdziwieni, że jako

30 Archiwum m.st. Warszawy, BOS, syg. 5852. Roman Piotrowski (1895-1988), architekt, studiował na Politechnice Lwowskiej i na Politechnice Warszawskiej, członek grupy Praesens; w latach 1930-1934 architekt ZUS - współautor projektu kolonii domków jednorodzinnych ZUS na Żoliborzu (1935), 1934-1944 kierownik techniczny w Towarzystwie Osiedli Robotniczych. W latach 1940-1944 pracował w Pracowni Architektoniczno-Urbanistycznej, a od 1942 r. był jej kierownikiem. W latach 1944-1947 poseł KRN, 1945-1949 kierownik BOS, 1945-1947 wiceprezydent Warszawy, 1947 r. - komisarz odbudowy stolicy, 1947-1949 wiceminister odbudowy, 1949-1956 minister budownictwa miast i osiedli, 1947-1956 poseł na Sejm. Encyklopedia Warszawy, op.cit., s. 639; J.S. Majewski, T. Markiewicz, op.cit., s. 40; T. Mołdawa, Ludzie władzy 1944-1991. Władze państwowe i polityczne Polski według stanu na dzień 28 II 1991, Wydawnictwo Naukowe PWN, Warszawa 1991, s. 411.

31 Archiwum m.st. Warszawy, BOS, syg. 6585. 
właściciel budynku nie zostali poinformowani wcześniej o poczynionych przygotowaniach. W zaistniałej sytuacji Senat upoważnił profesora Edwarda Lipińskiego do podjęcia rozmów w tej sprawie z ministrem odbudowy Michałem Kaczorowskim i prezydentem miasta Stanisławem Tołwińskim ${ }^{32}$. Podczas kolejnego zebrania Senatu rektor J. Loth poinformował o omówieniu z prof. Zygmuntem Kamińskim ${ }^{33}$, dziekanem Wydziału Architektury Politechniki Warszawskiej, warunków korzystania przez PW z gmachu A, w zamian za jego odbudowę. Rektor J. Loth zaproponował oddanie do dyspozycji Wydziałowi Architektury połowy gmachu na okres trzech lat. W tym momencie wydawało się, że gmach A zostanie odbudowany wspólnymi siłami SGH i Politechniki Warszawskiej. Ostatecznie jednak strony nie doszły do porozumienia w sprawie kosztów i podziału odbudowanego gmachu. W związku z tym Senat SGH podjął decyzję o samodzielnej odbudowie, a delegatem do spraw odbudowy mianował prof. Stanisława Skrzywana ${ }^{34}$.

32 Protokoły posiedzeń Senatu nr 293-370 (28 III 1945-30 VIII1949), Protokół posiedzenia Senatu Szkoły Głównej Handlowej w Warszawie, odbytego w dniu 10 lipca 1945 r., s. 68, Archiwum SGH. Michał Kaczorowski (1897-1975), absolwent Wydziału Prawa i Nauk Ekonomicznych. Przed wojną pracownik Biura Ekonomicznego Prezesa Rady Ministrów i naczelnik Wydziału Ekonomicznego w Ministerstwie Skarbu. W tym samym czasie był członkiem Zarządu Polskiego Towarzystwa Reformy Mieszkaniowej, wiceprzewodniczącym Komisji Planu Regionalnego Warszawy oraz jednym ze współzałożycieli Towarzystwa Osiedli Robotniczych. W czasie okupacji był członkiem Komisji Urbanistycznej Warszawy i brał udział w konspiracyjnych pracach Biura Planu Regionu Warszawskiego i Biura Planu Krajowego. 8 września 1939 r. wstąpił do PPS, w latach 1945-1948 był członkiem Rady Naczelnej PPS. W listopadzie 1944 r. został mianowany szefem Biura Planowania i Odbudowy przy Prezydium PKWN, potem przy Prezydium Rady Ministrów. Pełnił tę funkcję do kwietnia $1945 \mathrm{r}$. W latach 1945-1949 był Ministrem Odbudowy oraz prezesem Głównego Urzędu Planowania Przestrzennego, potem zajął się pracą naukową. Był też polskim delegatem na Konferencję Pokojową w Paryżu. Od 1949 r. do 1971 r. dyrektor Instytutu Budownictwa Mieszkaniowego. Wieloletni wykładowca Politechniki Warszawskiej. [S. Leszczyński, Michał Kaczorowski 27 IX 1897-15 III 1975, „Kronika Warszawy” 1975, nr 4, s. 125-127; Michał Kaczorowski, „Polityka” 1980, nr 9, s. 5; B. Poznańska, Prof. dr Michał Kaczorowski, „Stolica” 1975, nr 14, s. 11]. Stanisław Tołwiński (1895-1969), działacz socjalistyczny, a później komunistyczny, w latach 1915-1917 więziony przez władze carskie, 1917 r. członek Zjednoczenia Socjalistów Polskich, uczestnik rewolucji bolszewickiej, 1918-1920 członek PPS. Od 1919 r. mieszkał w Warszawie. W latach 1925-1939 współzałożyciel i członek zarządu WSM, podczas okupacji dyrektor Zarządu Społecznego Przedsiębiorstwa Budowlanego w Warszawie. Utrzymywał kontakty z RPPS i PPR, 1945-1947 poseł do KRN i na Sejm (1947-1957), w latach 1945-1950 prezydent Warszawy. Od 1946r. członek PPR, a następnie PZPR. W latach 1950-1952 dyrektor generalny do spraw rad narodowych w Prezydium Rady Ministrów, 1953-1967 zastępca szefa Urzędu Rady Ministrów. Jego imieniem nazwano ulicę na Żoliborzu. Encyklopedia Warszawy, op.cit., s. 888.

33 Kursy Akademickie zorganizowane w Częstochowie objęły także nauki techniczne. Wydział Architektury, liczący wówczas 18 słuchaczy, zainaugurował naukę 6 grudnia 1944r. pod kierownictwem prof. Z. Kamińskiego. [Politechnika Warszawska 1915-1965, op.cit., s. 105-106]. Zygmunt Kamiński (1988-1969), malarz, rysownik, grafik, studiował w Warszawskiej Szkole Sztuk Pięknych i w krakowskiej ASP, współorganizator Politechniki Warszawskiej w $1915 \mathrm{r}$. i wieloletni wykładowca tej uczelni. W latach 1929-1931 i 1936-1937 był dziekanem Wydziału Architektury. Encyklopedia Warszawy, op.cit., s. 314; Warszawska Szkoła Architektury..., op.cit., s. 242.

34 Protokoły posiedzeń Senatu nr 293-370 (28 III 1945-30 VIII 1949), Protokół z posiedzenia Senatu Szkoły Głównej Handlowej w Warszawie odbytego w dniu 25 września 1945 r., s. 95, Archiwum SGH; G. Jamroziak, Pierwsze lata powojenne. Szkoła Główna Handlowa 1945-1949, w: Historia Szkoły Głównej 
W lutym 1946 r., na wniosek Stanisława Skrzywana, Senat SGH postanowił powołać dwa ciała zbiorowe do spraw budowlanych - Komitet Budowlany (organ oficjalny składający się z małej liczby osób, mający do wykonania przede wszystkim wszelkiego rodzaju sprawy formalne, związane $z$ odbudową) w składzie J. Loth - przewodniczący, S. Skrzywan - zastępca przewodniczącego, członkowie inż. Cz. Niezabitowski jako delegat Ministerstwa Odbudowy i inż. Jan Koszczyc-Witkiewicz jako kierownik robót, oraz Komisję Budowlaną Senatu w składzie rektor Aleksy Wakar oraz profesorowie: J. Loth, E. Lipiński, E. Dąbrowski i S. Skrzywan, której zadaniem było prowadzenie właściwej polityki budowlanej Szkoły i przygotowanie materiałów dla Komitetu zgodnie z potrzebami i interesem Szkoły ${ }^{35}$. Następnie upoważniono rektora Aleksego Wakara do zaciągnięcia pierwszej pożyczki hipotecznej w Banku Gospodarstwa Krajowego na sumę $10 \mathrm{mln}$ zł jednorazowo lub częściami na nieruchomość SGH (nr hipoteczny 8391) przy ul. Rakowieckiej $6 \mathrm{w}$ celu zabezpieczenia, remontu i odbudowy budynków SGH w Warszawie ${ }^{36}$. W kwietniu 1946 r. Komisja rozpatrzyła projekt rozplanowania pomieszczeń w gmachu A i przeznaczyła parter w zasadzie na te same cele, na jakie był używany dawniej (z drobnymi modyfikacjami), pierwsze piętro na instytuty i zakłady (również z koniecznymi zmianami), zaś drugie piętro na kursy specjalne i pracownie języków obcych ${ }^{37}$.

Roboty budowlane prowadziło przedsiębiorstwo Martens i Daab, to samo, które budowało gmach przed wojną. Przetarg na urządzenia wodociągowo-kanalizacyjne wygrała firma Kamler i S-ka, zaś na instalację elektryczną - firma J. Kołodziejski ${ }^{38}$. Przy odbudowie, obok polskich specjalistów, pracowali jeńcy niemieccy ${ }^{39}$. Szczególną trudność stanowiło niedotrzymanie terminów dostawy stolarki budowlanej, której wykonania na mocy przetargu podjęło się Państwowe Zjednoczenie Przedsiębiorców Budowlanych w Jeleniej Górze ${ }^{40}$. Opóźnienia związane z dostawą stolarki znacznie utrudniały terminowe prowadzenie prac.

Handlowej $w$ Warszawie..., op.cit., s. 165; Z. Landau, Stanisław Skrzywan (1902-1971), w: Poczet wybitnych profesorów SGH-SGPiS, Oficyna Wydawnicza SGH, Warszawa 1986, s. 271-272.

35 Protokoły posiedzeń Senatu nr 293-370 (28 III 1945-30 VIII 1949), Protokół 314 z posiedzenia Senatu Szkoły Głównej Handlowej z 12.02.1946, s. 197, Archiwum SGH.

36 Protokoły posiedzeń Senatu nr 293-370 (28 III 1945-30 VIII 1949), Protokół 316a z posiedzenia Senatu Szkoły Głównej Handlowej z dnia 9 marca 1946 r., s. 21, Archiwum SGH.

37 Protokoły posiedzeń Senatu nr 293-370 (28 III 1945-30 VIII 1949), Protokół 318 z posiedzenia Senatu Szkoły Głównej Handlowej w Warszawie z dnia 30 kwietnia 1946 r., s. 229, Archiwum SGH.

38 Protokoły posiedzeń Senatu nr 293-370 (28 III 1945-30 VIII 1949), Protokół 305 z posiedzenia Senatu SGH w Warszawie odbytego w dniu 23 października 1945 r., s. 146; Protokół z posiedzenia Senatu Szkoły Głównej Handlowej w Warszawie odbytego dnia 23 października 1945 r., s. 126, Archiwum SGH; Archiwum m.st. Warszawy, Warszawska Dyrekcja Odbudowy, syg. 1178.

39 A. Koźmiński, Wspomnienia absolwentów uczelni, „Bank i Kredyt” 2006, nr 5-6, s. 100.

40 Protokoły posiedzeń Senatu nr 293-370 (28 III 1945-30 VIII 1949), Protokół 323 z posiedzenia Senatu Szkoły Głównej Handlowej w Warszawie z dnia 20 lipca 1946 r., s. 283, Archiwum SGH. 
Prace przy odbudowie gmachu A były finansowane z kredytów Ministerstwa Odbudowy ${ }^{41}$. Budową osobiście interesował się minister skarbu, a zarazem absolwent przedwojennej SGH, Konstanty Dąbrowski ${ }^{42}$. Dzięki jego pomocy udało się szybko odbudować gmach oraz uzyskać potrzebne kredyty. Całkowity koszt budowy gmachu A wyniósł $52 \mathrm{mln}$ zł, na których pokrycie Szkoła otrzymała $51 \mathrm{mln}$ zł. Powstał zatem deficyt około $1 \mathrm{mln}$ zł, który Szkoła musiała pokryć ze środków specjalnych ${ }^{43}$. Stanisław Skrzywan po latach odsłonił trochę kulisy finansowania odbudowy, mówiąc: „Dzisiaj już można powiedzieć, że pieniądze na odbudowę szkoły, które uzyskaliśmy w 1945 roku, były zdobyte trochę nielegalnie. Wykorzystaliśmy po prostu naszych wychowanków. Budynek A został odbudowany w niebywałym tempie i tak tanio, że władze nie chciały wierzyć, że można to było zrobić. Ponieważ chcieliśmy, by nikt nie mógł nam czynić żadnych zarzutów, przeprowadziliśmy tak zwaną kolaudację przez miejskie władze budowlane. To znaczy obmierzono dokładnie budynek, sprawdzono całą dokumentację i wszystkie rachunki. Był to chyba jedyny budynek w Warszawie skolaudowany w ten sposób. A że to wszystko odbyło się tak szybko i tak tanio... Ba, ale nie było przy tym żadnej administracji..." ${ }^{4}$.

Prace rozpoczęto w listopadzie $1945 \mathrm{r}$. Najpierw wykonano remont dachu i odbudowano pomieszczenia na trzecim piętrze, przeznaczając je na bursę do 100 studentów i studentek oraz stołówkę „Bratniaka”. Pierwsi studenci zamieszkali w nowej bursie w marcu $1946 \mathrm{r}$. W dalszej kolejności odbudowano sale dydaktyczne i wykładowe na parterze i pierwszym piętrze, co umożliwiło prowadzenie w nich zajęć już od stycznia $1947 \mathrm{r}$. Ostatnim etapem prac była odbudowa auli. Odremontowaną aulę oddano do użytku we wrześniu 1947 r. ${ }^{45}$ Dnia 15 października 1947 r. w auli gmachu A odbyła się uroczysta inauguracja roku akademickiego, w której uczestniczyli także delegaci rządu - minister Konstanty Dąbrowski oraz premier Edward Osóbka-Morawski ${ }^{46}$. Dwa lata później, wiosną 1949 r., rektor Andrzej Grodek doprowadził do wmurowania, przed wejściem do auli w Budynku A, dwóch tablic upamiętniających przedwojennych profesorów WSH-SGH ${ }^{47}$.

41 Archiwum m.st. Warszawy, BOS, syg. 85.

42 M.K., Szkoła Główna Handlowa w Warszawie, „Stolica” 1947, nr 44, s. 4, 8.

43 Protokoły posiedzeń Senatu nr 293-370 (28 III 1945-30 VIII 1949), Protokół 343 z posiedzenia Senatu Szkoły Głównej Handlowej w Warszawie z dnia 30 września 1947 r., s. 467, Archiwum SGH.

44 S. Skrzywan, Opowiada jeden z profesorów, „Świat” 1966, nr 42, s. 11.

45 S. Skrzywan, Nasze gmachy, „Gazeta Młodego Ekonomisty” 1956, nr 2, s. 3; J. Górski, op.cit., s. 456; I. Kostrowicka, op.cit., s. 423; M.K., op.cit. Warto nadmienić, że w latach 1947-1948 na podstawie decyzji Senatu SGH wybudowano duży gmach w Łodzi, przeznaczony dla oddziału SGH, liczącego wówczas około 100 studentów. Został on później przejęty przez Wyższą Szkołę Ekonomiczną w Łodzi.

46 M.K., op.cit.

47 W. Sadowski, Ze wspomnień rektorów, „Bank i Kredyt” 2006, nr 5-6, s. 17. 
Równolegle z odbudową Budynku A oraz pracami remontowymi w budynku Biblioteki ${ }^{48}$ trwały prace nad zagospodarowaniem terenu kampusu. Staraniem pracowników uczelni doprowadzono do dobrego stanu ogród, część terenu przeznaczono na ogródki działkowe dla pracowników. Staraniem Stowarzyszenia Studentów Bratnia Pomoc zostało odbudowane boisko, na co w maju 1946 r. uzyskano dotację z Biura Odbudowy Stolicy w wysokości 55 tys. $\mathrm{z}^{49}$. Udało się także udostępnić czytelnikom Bibliotekę ${ }^{50}$.

\section{Bibliografia}

\section{Materiały archiwalne}

Archiwum Państwowe m.st. Warszawy

Biuro Odbudowy Stolicy (nr zespołu: 25).

Warszawska Dyrekcja Odbudowy (numer zespołu: 26).

Archiwum SGH

Protokoły posiedzeń Senatu nr 293-370 (28 III 1945-30 VIII 1949).

\section{Źródła i opracowania opublikowane}

Buczek S., Politechnika, „Stolica” 1947, nr 10, s. 5.

Działalność dydaktyczna Wyższej Szkoły Handlowej - Szkoły Głównej Handlowej w latach 1915-1939, „Monografie i Opracowania” nr 388, Oficyna Wydawnicza SGH, Warszawa 1994.

Dziesięciolecie Politechniki Warszawskiej w Polsce Ludowej 1945-1955, Wydawnictwa Politechniki Warszawskiej, Warszawa 1956.

Dziesięć lat Politechniki Warszawskiej w Polsce Ludowej, red. H. Śmigielski, PWN, Warszawa 1955.

48 Szerzej na temat Biblioteki SGH po II wojnie światowej patrz: Historia Biblioteki Szkoły Głównej Planowania i Statystyki 1906-1978, oprac. J. Skiwska, maszynopis, Biblioteka SGH, Warszawa 1979; A. Jarosz-Nojszewska, Powojenne losy kampusu, w: Historia zabytkowego..., op.cit., s. 115-134.

49 Archiwum m.st. Warszawy, BOS, syg. 85; 3491. Prace przeprowadziło w czerwcu 1946r. Przedsiębiorstwo Inżynieryjno-Budowlane inżyniera Tadeusza Adamczyka. Ogólny koszt przygotowania boiska wyniósł jednak więcej, niż wynosiła dotacja otrzymana z BOS. Całość prac zamknęła się kwotą $90225 \mathrm{zł}$. W tej sytuacji Zarząd Stowarzyszenia zwrócił się do BOS z prośbą o pokrycie reszty kosztów, jednak otrzymał odpowiedź odmowną. Wówczas Zarząd zwrócił się z prośbą o wyasygnowanie brakującej kwoty $35225 \mathrm{zł}$ do Warszawskiej Dyrekcji Odbudowy, ponieważ Stowarzyszenie nie posiadało środków własnych na tak duże inwestycje, a otrzymywane z Ministerstwa Oświaty subsydia były odgórnie przeznaczone na stypendia dla niezamożnych studentów oraz dofinansowanie stołówek studenckich.

50 A. Jarosz-Nojszewska, Powojenne losy kampusu, op.cit., s. 116-117. 
Encyklopedia Warszawy, Wydawnictwo Naukowe PWN, Warszawa 1994.

Górski J., Warszawa w latach 1944-1949. Odbudowa, PWN, Warszawa 1988.

Historia Szkoły Głównej Handlowej w Warszawie, 1906-2006, red. W. Morawski, Oficyna Wydawnicza SGH, Warszawa 2006.

Historia zabytkowego kampusu Szkoły Głównej Handlowej w Warszawie, red. W. Morawski, Oficyna Wydawnicza SGH, Warszawa 2015.

Hryniewiecki J., Szczegółowy plan zabudowy Mokotowa, „Stolica” 1947, nr 9, s. 4.

Jarosz-Nojszewska A., Powojenne losy kampusu, w: Historia zabytkowego kampusu Szkoty Głównej Handlowej w Warszawie, red. W. Morawski, Oficyna Wydawnicza SGH, Warszawa 2015, s. 115-134.

Jarosz-Nojszewska A., Powstanie Szkoły Głównej Handlowej w Warszawie i jej kampusu, w: Historia zabytkowego kampusu Szkoły Głównej Handlowej w Warszawie, red. W. Morawski, Oficyna Wydawnicza SGH, Warszawa 2015, s. 49-60.

Jarosz-Nojszewska A., Wyższa Szkoła Handlowa 1915-1933, w: Historia Szkoły Głównej Handlowej $w$ Warszawie, 1906-2006, red. W. Morawski, Oficyna Wydawnicza SGH, Warszawa 2006, s. 43-64.

Kaliński J., Szkoła Główna Handlowa 1906-1996 (Wykład wygłoszony 17 kwietnia 1996 r.), w: Z obchodów 90-lecia Szkoły Głównej Handlowej, Oficyna Wydawnicza SGH, Warszawa 1996.

Kostrowicka I., Szkoła Główna Planowania i Statystyki w Warszawie, w: Nauka i szkolnictwo wyższe w Warszawie, PWN, Warszawa 1987, s. 416-431.

Koźmiński L., Sytuacja po zakończeniu wojny, w: Szkoła Główna Handlowa w latach 1939-1945, red. J. Nowicki, „Monografie i Opracowania” nr 187, Wydawnictwa Uczelniane SGPiS, Warszawa 1986.

Koźmiński A., Wspomnienia absolwentów uczelni, „Bank i Kredyt” 2006, nr 5-6.

Królikowski L., Ostrowski M., Rozwój przestrzenny Warszawy, Mazowieckie Centrum Kultury i Sztuki Agencja Wydawnicza Egros, Warszawa 2009.

Kto jest kim w Polsce 1984. Informator biograficzny, Wydawnictwo Interpress, Warszawa 1984.

Kto odbudowuje Warszawę, „Stolica” 1947, nr 34, s. 6-7.

Landau Z., Stanisław Skrzywan (1902-1971), w: Poczet wybitnych profesorów SGH-SGPiS, Wydawnictwa Uczelniane SGPiS, Warszawa 1986.

Leszczyński S., Michał Kaczorowski 27 IX 1897-15 III 1975, „Kronika Warszawy” 1975, nr 4, s. 125-127.

Leśniakowska M., Architekt Jan Koszczyc Witkiewicz (1881-1958) i budowanie w jego czasach, Instytut Sztuki PAN, Warszawa 1998.

M.K., Szkoła Główna Handlowa w Warszawie, „Stolica” 1947, nr 44, s. 4, 8.

Macieja J., Wrzosek S., Szkoła Główna Planowania i Statystyki w Warszawie, w: Dzieje Mokotowa, PWN, Warszawa 1972, s. 421-433. 
Mężyński A., Biblioteki Warszawy w latach 1939-1945, Ministerstwo Kultury i Dziedzictwa Narodowego, Warszawa 2010.

Michał Kaczorowski, „Polityka” 1980, nr 9, s. 5.

Ministerstwo Przemysłu i Handlu w al. Niepodległości, „Stolica” 1947, nr 22, s. 2.

Mołdawa T., Ludzie władzy 1944-1991. Władze państwowe i polityczne Polski według stanu na dzień 28 II 1991, Wydawnictwo Naukowe PWN, Warszawa 1991.

Mróz W., Działalność dydaktyczna Wyższej Szkoły Handlowej - Szkoły Głównej Handlowej w latach 1915-1939, Oficyna Wydawnicza SGH, Warszawa 1994.

Paprotny M., Jan Koszczyc-Witkiewicz - twórca gmachów SGH, „Mówią wieki” 2006, nr 4, s. 29-31.

Pierwsi powojenni. Wspomnienia pierwszych powojennych studentów Wydziału Rolniczego SGGW, Fundacja Rozwój SGGW, Warszawa 2002.

Politechnika Warszawska 1915-1965, PWN, Warszawa 1965.

Politechnika Warszawska w ćwierćwieczu Polski Ludowej, PWN, Warszawa 1970.

Pot., Reporterska włóczęga. Aleja Niepodległości, „Stolica” 1947, nr 35, s. 4.

Poznańska B., Prof. dr Michał Kaczorowski, „Stolica” 1975, nr 14, s.11.

Sadowski W., Ze wspomnień rektorów, „Bank i Kredyt” 2006, nr 5-6.

Sikorska M., Biuro Odbudowy Stolicy - organizacja, zadania, pracownicy, w: Archiwum Biura Odbudowy Stolicy, Stowarzyszenie Przyjaciół Archiwum Państwowego m.st. Warszawy, Warszawa 2012, s. 9-14.

Skrzywan S., Nasze gmachy, „Gazeta Młodego Ekonomisty” 1956, nr 2, s. 3.

Skrzywan S., Opowiada jeden z profesorów, „Świat” 1966, nr 42, s. 11.

Szkoła Główna Gospodarstwa Wiejskiego w Polsce Ludowej 1945-1956, red. W. Herman, w: Księga pamiątkowa Szkoły Głównej Gospodarstwa Wiejskiego w Warszawie 1906-1956, t. 1, PWRiL, Warszawa 1958.

Szkoła Główna Handlowa w latach 1939-1945, red. J. Nowicki, „Monografie i Opracowania” nr 187, Wydawnictwa Uczelniane SGPiS, Warszawa 1986.

Tanewski P., Wokół SGH: domy, ludzie, zdarzenia, Oficyna Wydawnicza SGH, Warszawa 2012.

Tanewski P., Wokół SGH: domy, ludzie, zdarzenia, t. 2, Oficyna Wydawnicza SGH, Warszawa 2014.

Ulica Rakowiecka kończy swoją odbudowę, „Stolica” 1947, nr 21, s. 2.

Warszawa wielkomiejska. Plac Unii i okolice, EKBIN Studio PR Ewa Kielak, Warszawa 2013.

Warszawska Szkoła Architektury. 50-lecie Wydziału Architektury Politechniki Warszawskiej, PWN, Warszawa 1967.

Witkiewicz-Koszczyc J., Sprawozdanie z budowy gmachu doświadczalnego Wyższej Szkoły Handlowej w Warszawie, WSH, Warszawa 1927. 
Wysocki W., Archiwum Akt Nowych w Warszawie 1930-1946. Dzieje i działalność, „Teki Archiwalne" 2004, t. 8, s. 19-28.

Wyższa Szkoła Handlowa, Szkoła Główna Handlowa, Miejska Szkoła Handlowa 1906-1945, „Monografie i Opracowania” nr 134, Wydawnictwa Uczelniane SGPiS, Warszawa 1984.

\section{Opracowanie nieopublikowane}

Historia Biblioteki Szkoły Głównej Planowania i Statystyki 1906-1978, oprac. J. Skiwska, maszynopis, Biblioteka SGH, Warszawa 1979.

\section{Reconstruction of the Research Building of the Warsaw School of Economics after the World War II}

In 2008 the Campus of the Warsaw School of Economics (SGH) was entered into the register of monuments. The Research Pavilion, so called Building A, is the oldest of the campus buildings. It was constructed between WWI and WWII according to the design of Jan Koszczyc-Witkiewicz, one of the most renowned contemporary architects. During WWII, immediately after the end of the Warsaw Uprising, the Germans burnt down this building despite the signed capitulation agreement guaranteeing the protection of Polish national heritage monuments. The building accommodated at that time the archives of Polish pre-war state institutions, which were completely destroyed. The building was reconstructed after the WWII as a results of the efforts of the university authorities and personal involvement of Professor Stanisław Skrzywan. The paper presents the process of reconstruction of the listed building based on archive sources - the Archives of the capital city of Warsaw (the archives of the Capital Reconstruction Bureau) and SGH Archives (the minutes from meetings of the SGH Senate), the memoires and contemporary press.

Keywords: WSH, Warsaw School of Economics, Research Pavilion, Building A, SGH Campus, Jan Koszczyc-Witkiewicz, SGGW, Capital Reconstruction Bureau, Andrzej Grodek, ul. Rakowiecka 


\section{Reconstruction du Bâtiment Expérimental de l'École Centrale du Commerce (SGH) à Varsovie après la llème Guerre Mondiale}

En 2008 le Campus de l'École Centrale du Commerce (SGH) à Varsovie est inscrit au registre des monuments. Le plus ancien des bâtiments sur le territoire du campus c'est le Pavillon Expérimental, le dit Bâtiment A. Il est construit dans la période d'entre-guerres selon le projet d'un des architectes les plus connus de cette époque, c'est-à-dire de Jan Koszczyc-Witkiewicz. Durant la IIème Guerre Mondiale, directement après la fin de l'Insurrection de Varsovie, malgré la stipulation de l'accord de capitulation assurant la protection des édifices appartenant à l'héritage national polonais, les Allemands ont brûlé ce bâtiment. À ce moment-là, l'édifice était un lieu de conservation des dossiers offciels polonais qui sont entièrement détruits. Après la IIème Guerre Mondiale, le bâtiment est reconstruit grâce aux efforts des autorités universitaires et à l'engagement personnel du professeur Stanisław Skrzywan. L'article présente le processus de reconstruction de l'édifice monumental en utilisant les fonds d'archives - l'Archive de la ville-capitale de Varsovie (dossier du Bureau de la Reconstruction de la Capitale) et l'Archive de la SGH (procès-verbaux du Sénat de la SGH), les mémoires et la presse de cette époque.

Mots-clés: WSH, l'École Centrale du Commerce (SGH), le Pavillon Expérimental, Bâtiment A, Campus, Jan Koszczyc-Witkiewicz, SGGW, Bureau de la reconstruction, Andrzej Grodek, ul. Rakowiecka

\section{Реконструкция лабораторного здания Варшавской школы экономики после Второй мировой войны}

В 2008 году кампус Варшавской школы экономики был внесен в реестр памятников. Самым старым из расположенных на его территории зданий является лабораторный павильон т. н. Здание А. Оно было построено в межвоенный период по проекту одного из самых известных тогда архитекторов - Яна Кошиц-Виткевича. Во время Второй мировой войны, сразу после Варшавского восстания, несмотря на условия капитуляции, гарантирующее защиту польских памятников, немцы сожгли здание. Хранимые в здании архивы польских довоенных государственных учреждений были полностью уничтожены. После Второй мировой войны здание было восстановлено благодаря усилиям властей учебного заведения и личной приверженности 
этому делу профессора Станислава Скшивана. Статья представляет процесс реконструкции здания при использовании архивных источников - архива города Варшавы (архив Бюро восстановления столицы), архива Варшавской школы экономики (протоколы Сената), мемуаров и материалов прессы.

Ключевые слова: Высшая школа коммерции, Варшавская школа экономики, лабораторное здание, здание А, кампус Варшавской школы экономики, Ян Кошиц-Виткевич, Сельскохозяйственный университет в Варшаве, Бюро восстановления столицы, Анджей Грудек, ул. Раковецка 